\title{
Construction and Economy of Plant Stems as Revealed by Use of the Bic-method
}

\author{
ULRICH KULL* $\dagger$, ASTRID HERBIG* and FREI OTTO \\ * Biologisches Institut der Universität Stuttgart, Pfaffenwaldring 57 D-(W)-7000 Stuttgart 80 and $\ddagger$ Institut für \\ Leichte Flächentragwerke der Universität Stuttgart, Pfaffenwaldring 14, D-(W)-7000 Stuttgart 80, Germany
}

Accepted: 29 October 1991

\begin{abstract}
The Bic-method, developed by F. Otto for the investigation and classification of light-weight structures in architecture and then also applied to constructions in nature, can be used for mechanical analysis of plants. It allows statements on tension and pressure stability of plant stems and a direct comparison of stems with different anatomy. The multiplication of the Bic-value by an energy value (construction cost or energy content of the plant organ) results in a dimensionless constructive expenditure value, which is comparable to the value of the construction economy in architecture. This value may then be related to the average lifespan of the plant organ.

Stems of Ephedra foeminea, Pachysandra terminalis, and Taxus baccata as well as flower stalks of Cyclamen persicum and Taraxacum officinale are investigated to show the applicability of the method. The lowest Bic-values (highest mechanical stability) are found for the lignified stems of Ephedra and Taxus. The constructive expenditure values are higher in herbaceous than in woody axes; in relation to the average life span the long-hiving lignified tissues show by far the lowest values. The very high values of the flower-stalks are attributed to the fact that short-lived organs also need a minimum expenditure of materials and energy for their construction.
\end{abstract}

Key words: Stem, Bic-value, construction cost, energy expenditure value, stress-strain graph, Cyclamen persicum, Ephedra foeminea, Pachysandra termunalis, Taraxacum officinale (dandelion), Taxus baccata (yew), flower stalk.

\section{INTRODUCTION}

Mechanical properties of plant stems have been investigated since the 19th century. Many of the data, especially those reported by Schwendener (1874) and Rasdorsky (1928, 1937), are found in textbooks; a short historical survey can be found in Mosbrugger (1990). During the last two decades there has been increasing interest in the mechanics of structural biomaterials (for review see Wainwright et al., 1976; Vincent, 1982). However, living intact plant stems have seldom been investigated quantitatively. This is mainly attributed to their anisotropy. Stems consist of tissues of very different elastic moduli and therefore form a composite material. So it is not possible to determine by stress-strain experiments the elastic moduli of whole stems accurately. However, an idealized elastic modulus for the linear part of the stress-strain curve may be calculated; another method for the calculation of an (idealized) elastic modulus from bending data was described by Nachtigall, Wisser and Wisser (1986) who applied it to grasses. Alternatively, it is possible to make separate measurements on the different tissues and then calculate the mechanical efficiency from their relative proportions in the stem. Useful theoretical considerations regarding this method and its applicability in the mechanics of plant axes and in palaeobotany were published by Speck and Vogellehner (1988), Spatz, Speck and Vogellehner (1990) and Speck, Spatz and Vogellehner (1990). One main problem is the measurement of the crosssection of the different tissues. Without a clear definition of

† For correspondence. this area the measurement of strain seems problematic. Since the area is used for the calculations one has to decide whether to consider the whole cross section of stem tissues or only the area of the cell walls.

Size, shape and structure of plant stems underlie mechanical constraints (Mosbrugger, 1990; Speck et al., 1990). A direct comparison of stems of various species with different stem architecture and load capacities would be desirable not only from an evolutionary, but also from an ecological point of view.

This problem may be solved by using the rather simple Bic-method of Otto (Schaur, 1979; Otto, 1985 b) which was invented for the description of light weight structures in general. Using this method, it is not necessary to determine any area of a cross-section, but to weigh the axes being investigated which is simpler and rather unequivocal. Here we describe the principles of the Bic-method applied to plant axes and show its applicability as a good approximation based on the results obtained from selected species.

The Bic-value is a measure of the mechanical stability of a piece of matter or a construction related to its mass. A construction of high mechanical effectiveness but low mass (low energetic expenses) in engineering is called a lightweight structure, which is characterized by a low Bic-value. When the Bic-value of a plant organ is multiplied by the energy content of the organ or by the energy expenditure for constructing this organ (measured as an energy content value), a dimensionless value is obtained, which is a constructive expenditure value. When it is low, the expenditure of the plant to reach its load capacity is small and 
the construction may be considered as mechanically effective.

However, because the different tissues are not examined separately, it is not possible to determine which tissue is most responsible for the effectiveness of the construction and also why any construction is more effective than another one.

\section{THEORETICAL BASIS}

\section{The Bic-method}

The method was used first by Otto (1954) and the term 'Bic' coined later (Otto, 1968). It has since been used in many publications regarding structures especially in architecture. The Bic-value is defined as the ratio of the mass, $m$, of an object to its maximum capability to transmit forces of a given load condition. The Bic therefore refers to the case of ultimate load, at which the object is destroyed or permanently deformed. If an object is loaded to failure, the Bic can be determined from the ultimate load, $F$, the transmission distance, $s$, and the mass of the object, $m$ :

$$
\text { Bic }=\frac{m}{F s}\left(\mathrm{~g} \mathrm{~N}^{-1} \mathrm{~m}^{-1}\right) .
$$

The Bic depends not only on the mass of the object, but also on its form, its material, and the type and nature of loading.

A given object has different Bic-values for different states of loading, therefore each Bic-value has to be related to a definite load type. Two objects of the same form but of different materials usually show different Bic-values even when the type and nature of loading are the same. The Bicvalue may also be considered as the mass (in $\mathrm{g}$ ) required in a given load condition to transmit $1 \mathrm{~N}$ over a distance of $1 \mathrm{~m}$. The Bic-value relates only to the failure of the material, not to failure by local buckling and by global (Euler) buckling. This must be taken into consideration especially in the pressure experiments.

In the case of an object whose form, and thereby its ability to transmit forces, are specific to a certain task, we can refer to the 'expenditure' of material. Expenditure is the mass required to fulfill a certain task. The Bic-value then is a measure of the expenditure (in $\mathrm{g}$ ) needed to perform the structural task. Objects with low Bic-values are more effective than those with high Bic-values. Their effectiveness is then the reciprocal of the Bic.

The Bic is largely independent of the absolute size of the object. For a given load, the Bic-value is a function of form and material, but usually not of the scale. Geometrically similar objects consisting of the same material(s) have, at least theoretically, the same Bic-values for the same nature of load.

To compare different constructions, the Bic-values are often presented in relation to the relative structural slenderness of the object (Schaur, 1979) which in this case is given by

$$
\lambda=\frac{s}{\sqrt{ } F}\left(\mathrm{~m} \mathrm{~N}^{-0 . s}\right)
$$

where $s$ is transmission distance of the load (m), and $F$ the ultimate load $(\mathrm{N})$. In plant mechanics, the relative slenderness according to Mosbrugger (1990) is defined by

$$
\Gamma_{r}=\frac{l^{\frac{3}{2}}}{d},\left(\mathrm{~m}^{0-5}\right)
$$

where $l$ is the length, and $d$ the diameter of the plant stem (as a column). For our purpose, this value may be used as well.

If objects show similar relative structural slenderness, they can be compared directly, independent of their form and material, by using the Bic-value. The Bic-value increases as the relative structural slenderness of objects stressed by bending or compression increases. In tension the Bic-value is less dependent on the structural slenderness.

\section{Economy}

The economy of a construction is the relation of its expenditure to its effectiveness. Expenditure here means the total energy expenditure which is necessary for the synthesis of the bearing mass.

As an energy value, the total calorific energy or the calorific energy of the ash-free plant substance may be used. Perhaps a more accurate value is the construction cost of the organs as defined by Williams et al. (1987), which can be calculated from calorific energy, $\mathrm{N}$-content, and ash content. Also, construction costs of non-storage compounds, maintenance costs (Merino, Field and Mooney, 1984) and energy expenditure values (Diamantoglou, Rhizopoulou and Kull, $1989 b$ ) may be calculated (see Material and Methods) and could be used as energy quantity for the calculation of the economy of the construction.

The Bic-value multiplied by an energy value, $E$, (referred to $1 \mathrm{~g}$ of dry matter) results in a dimensionless value, which we call the expenditure value of the construction, or the constructive expenditure value, $K$ :

$$
K=\text { Bic } E \text {. }
$$

$K$ is comparable to the value of the constructional economy in architecture. The smaller this value, the less the expenditure to obtain the measured load-capacity of the construction.

In a final step, the very different lifespans of plant species or plant organs can be taken into consideration. Some plant stems have a short lifetime (e.g. axes of ephemeral or annual species, stalks of flowers and fruits) and others, such as stems of woody plants, show durability. Therefore it makes sense to relate the expenditure value, $K$, to the average life span of the construction.

\section{MATERIALS AND METHODS}

\section{Plant material}

Stems of three different species were used:

1. Ephedra foeminea Forsskal (Ephedra fragilis Desf. ssp. campylopoda (C.A. Mey.) Asch u. Gräbner). A long lived evergreen, stemmed shrub without leaves, and an average 
stem lifespan (according to observations by Diamantoglou in Greece) of 3-6 years (Diamantoglou et al., 1989a,b). The species was erroneously determined as $E$. distachya; an inspection by $\mathrm{H}$. Freitag, Kassel demonstrated it to be $E$. foeminea.

2. Taxus baccata L. A woody plant; 1 and 2 year old twigs were used. Average twig lifespan of 5-10 years.

3. Pachysandra terminalis Sieb et Zucc. An evergreen non-woody chamaephyte; 1-3 year old stems were used. Average stem lifespan (in pots) of 4 years (compare with Yoshie et al., 1990).

For reasons of comparison, scapes of Taraxacum officinale Web. and pedicels of a hybrid of Cyclamen persicum Mill. were also investigated.

\section{Methods}

Mechanical investigations. Internodal lengths from the stems of herbaceous plants, and twigs of young woody plants, were cut for use. Nodes in some preliminary experiments led to mechanical weakness and therefore were omitted in all experiments. If possible, pieces of 3,5 and $7 \mathrm{~cm}$ lengths were used for the tension experiments. The transmission distance is the length of the free part of the axes, the fixed part has to be disregarded. Theoretically, the Bic-value in the tension experiments should be independent of the length of the stem used. On the other hand, the probability of a failure rises with the length of the piece. Therefore using Pachysandra we tested whether the failure and the length of the piece are correlated, but it was found that the variance in experiments with stems from different plants was greater than the supposed effect of the length.

All Bic-values were calculated using the dry mass of the axes. The introduction of the forces must be performed carefully and, most of all, gently.

Tension. For measuring the ultimate tensile load, the fixing of the plant must be firmer than the stem itself; on the other hand, the stem should not be hurt by fastening or be allowed to dry out. The best method to avoid damage was to glue the axes with cyanoacrylate glue (Epple bond 4202) mixed with sawdust, into covers of gelatine (halves of medical gelatine capsules). During the drying period of about $20 \mathrm{~min}$, the pieces were kept in a damp box. The gelatine covers at both ends of the stem were then fixed and hung up in a construction where they were loaded with increasing masses, and the ultimate load was measured as quickly as possible. Experiments in which the axes broke away from the fixation and those with fractures in the fixed part or near its boundary were omitted.

Pressure. Short pieces of the stems investigated were fastened to a pressure frame apparatus constructed as described by Otto (1985b). It is not necessary to fix the ends in a speical way. The mass was raised to failure by pressure. All experiments, in which failure by buckling occurred, were omitted. When elastic bending was observed, shorter pieces were used.

Cone-shaped axes. When plant axes show a distinct coneshape, a marked influence on the tension stability is observed. The Bic-values of tension load then become dependent on the length of the piece used for experiments, because the share of ineffective mass is smaller in shorter pieces. Since fixation is necessary in tension experiments it is not possible to use very short pieces of the stalks. Hence, conic stems have to be converted by calculation into cylindrical axes. In our experiments, this calculation was always necessary for Taxus. The conic shape may be characterized by the value:

$$
\frac{\text { lower area-upper area }}{\text { length }},
$$

which is in the range $0.8-1.6 \%$ (mean value $1.16 \%$; s.d. \pm 0.22 ). From the volume and the dry mass of the truncated cone the specific gravity is calculated as follows:

$$
\rho=\frac{m_{\kappa}}{V_{K}}=\frac{m_{\kappa}}{\frac{\pi s}{3}\left(\left(\frac{d_{0}}{2}\right)^{2}+\frac{\left(d_{0}+d_{\underline{v}}\right)}{4}+\left(\frac{d_{k}}{2}\right)^{2}\right)}\left(\mathrm{gm}^{-3}\right)
$$

where $V_{K}$ is the volume of the truncated cone, $m_{K}$ the dry mass of the truncated cone, $d_{0}$ the upper diameter, $d_{v}$ the lower diameter and $s$ is the transmission distance.

Using this value, the mass of the bearing cylinder is determined, which is then used to calculate the Bic-value:

$$
m_{\text {eyiloder }}=\rho V_{\text {eyinder }}=\rho \pi d_{0}^{2} \frac{s}{4}
$$

Because the failure usually occurred near the upper end, the upper diameter was used for the calculation.

Stress-strain graph. In some experiments using scapes of Taraxacum and stems of Pachysandra (1 year old) stressstrain graphs for tension were determined. For Pachysandra, a continuously recording apparatus was used to investigate the tension strength; the values for Taraxacum were obtained by individual measurements. For Taraxacum, not only pieces ( $2 \mathrm{~cm}$ long) of intact scapes, but also pieces of separated tissues (epidermis plus collenchyma; parenchyma plus bundles) were investigated. We succeeded in the separation of the tissues by carefully incising the scape longitudinally after bending and then pulling apart the separated ends. The stress was calculated using the total area of the cross section and also using only the area of epidermis plus collenchyma, which primarily sustains the load.

Statistical methods. First, the Gaussian distribution of the Bic-values measured for Pachysandra was checked, which is a pre-requisite for the application of the statistical methods employed.

For the calculated Bic-values, the standard deviations (s) and the coefficients of variation $(V)$ :

$$
V_{\mathrm{c}}=100 \times \frac{s}{\bar{x}}(\%)
$$

were calculated. They are included in Table 1.

Energy values. The calorific total energy content was measured by adiabatic calorimetry as described by Diamantoglou et al. $(1989 a, b)$. The ash content was determined gravimetrically after combustion of the plant material in a 
muffle furnace for $1.5 \mathrm{~h}$ at $500^{\circ} \mathrm{C}$. Based on the values obtained, the calculation of the energy equivalents was corrected and designated as the energy of ash-free material.

The total $\mathrm{N}$-content was measured by the Kjeldahlmethod as described by Diamantoglou and Kull (1988). The construction cost was calculated according to the method of Williams et al. (1987) using a value for growth efficiency $E_{0}=0.87$ (Diamantoglou et al., 1989b) and considering nitrate as the nitrogen source.

From the estimation of the contents of the storage substances (soluble sugars, starch, lipids), according to the methods described by Diamantoglou and Kull (1982), their energy contents were calculated and summed. This leads to the energy content of the storage products. The construction cost of the storage compounds was calculated as described by Diamantoglou et al. $(1989 b)$. The difference between the total construction cost and the construction cost of the storage substances may be considered as the construction cost of the non-storage substances which mainly comprise the load-bearing components of a tissue. In this calculation the secondary plant substances are disregarded and this is a major source of inaccuracy.

For Ephedra, the total energy content, the energy of ashfree materials, total construction cost and construction-cost of non-storage substances had been measured throughout the year (Diamantoglou et al., 1989a,b). For Taxus, the contents of storage compounds and their variation throughout a year's course had been investigated earlier (Distelbarth, Kull and Jeremias, 1984) and corresponding data on Pachysandra are available from unpublished results of Distelbarth.

\section{RESULTS AND DISCUSSION}

\section{Stress-strain diagrams}

In Fig. 1 stress-strain curves for tension in 1-year-old stems of Pachysandra are shown and Fig. 2 presents the same graphs for the scapes of Taraxacum. From these diagrams

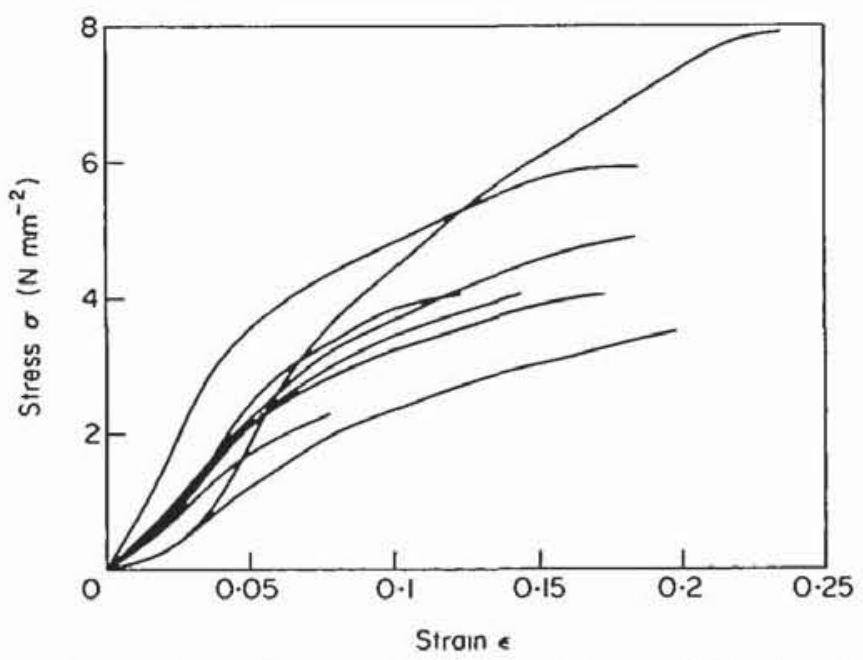

FIG. 1. Stress-strain diagrams for tension of 1-year-old Pachysandra terminalis stems.

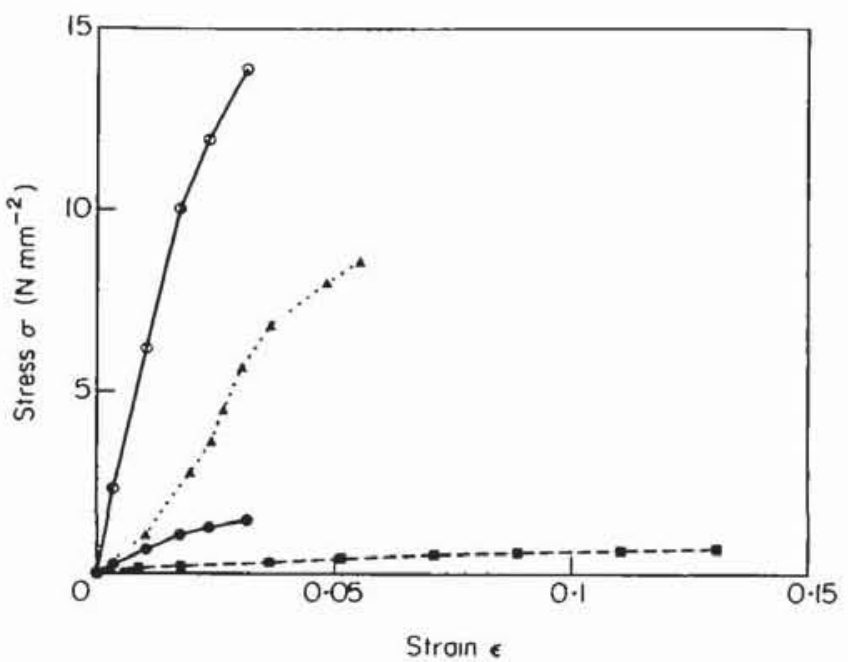

FIG. 2. Stress-strain diagrams for tension of whole axes and separated tissues of Taraxacum officinale scapes. For whole scapes, the stress was calculated using the area of only epidermis and collenchyma $(\mathrm{O}-\mathrm{O})$ and using the whole area of the cross-section (-) $(\mathbf{\Delta} \cdots \mathbf{\Delta})$ Epidermis plus collenchyma; ( $-\mathbf{D})$ parenchyma plus vascular bundles.

it may be seen that it is not possible to get clear values of Young's (elastic) moduli. The behaviour of the internodes by approximation may be described as elastic-plastic deformation; however, the sigmoidal shape of the curves does not really fit this description. Disregarding the deformation by very small loads, there is an approximately elastic behaviour connected with small deformations and a plastic behaviour for large ones. It is well known that in living, and especially in the herbaceous plants, turgor pressure and the ability to avoid big forces by elasticity are of major importance for their mechanical stability (Ullrich, 1951; Nachtigall et al., 1986; Dierks and Hafner, 1987; Speck and Vogellehner, 1988; Speck et al., 1990). The problems of an unequivocal measurement of the strain, which is a prerequisite for the calculation of Young's modulus, may be seen from Fig. 2, which shows that the elastic behaviour is not linear over a large range of stresses.

\section{Bic-values}

The Bic-values for compression and tension loads are shown in Table 1. The values for compression are always higher than those for tension; plants have to expend a greater mass to achieve their compression stability than to reach their tension stability. Therefore, failure by compression should be more frequent in plant axes than failure by tension. In woody plants, pre-stressing represents an energy saving device to reduce the peripheral compressive stress (Mosbrugger, 1990). The Bic-values of compression and tension together allow an estimation of the mechanical efficiency of the axes as a whole, because bending may be regarded as a composite effect which is separable into a tension load on one side of a stem and a compression load on the other side.

From many investigations on bending stress of woody 
TABLE 1. Bic-values for compression and tension load

\begin{tabular}{|c|c|c|c|c|c|c|c|c|c|}
\hline \multirow[b]{2}{*}{ Species } & \multicolumn{5}{|c|}{ Compression } & \multicolumn{4}{|c|}{ Tension } \\
\hline & $\begin{array}{l}\text { Age of } \\
\text { axes } \\
\text { (years) }\end{array}$ & $\begin{array}{c}B i c 10^{-4} \\
\left(\mathrm{gN}^{-1} \mathrm{~m}^{-1}\right)\end{array}$ & $\begin{array}{c}\text { No. } \\
\text { experiments }\end{array}$ & $s$ & $V_{c}(\%)$ & $\begin{array}{c}\text { Bic } 10^{-4} \\
\left(\mathrm{gN}^{-1} \mathrm{~m}^{-1}\right)\end{array}$ & $\begin{array}{c}\text { No. } \\
\text { experiments }\end{array}$ & $s$ & $V_{e}(\%)$ \\
\hline $\begin{array}{l}\text { Ephedra } \\
\text { foeminea }\end{array}$ & 2 & 617 & 8 & 90 & 14.5 & 168 & 26 & 57 & 340 \\
\hline $\begin{array}{l}\text { Pachysandra } \\
\text { terminalis }\end{array}$ & $\begin{array}{l}1 \\
2 \\
3\end{array}$ & $\begin{array}{l}1250 \\
1706 \\
1640\end{array}$ & $\begin{array}{r}9 \\
12 \\
13\end{array}$ & $\begin{array}{l}306 \\
197 \\
260\end{array}$ & $\begin{array}{l}24.4 \\
11.6 \\
15.7\end{array}$ & $\begin{array}{l}667 \\
465 \\
431\end{array}$ & $\begin{array}{l}47 \\
31 \\
10\end{array}$ & $\begin{array}{r}151 \\
126 \\
68\end{array}$ & $\begin{array}{l}22.6 \\
27.6 \\
15.6\end{array}$ \\
\hline $\begin{array}{l}\text { Taxus } \\
\text { baccata }\end{array}$ & $\begin{array}{l}1 \\
2\end{array}$ & $\begin{array}{r}1270 \\
617\end{array}$ & $\begin{array}{l}4 \\
9\end{array}$ & $\begin{array}{l}348 \\
100\end{array}$ & $\begin{array}{l}27 \cdot 3 \\
16 \cdot 2\end{array}$ & $\begin{array}{l}419 \\
375\end{array}$ & $\begin{array}{l}10 \\
10\end{array}$ & $\begin{array}{r}96 \\
101\end{array}$ & $\begin{array}{l}22 \cdot 8 \\
27 \cdot 3\end{array}$ \\
\hline $\begin{array}{l}\text { Taraxacum } \\
\text { officinale }\end{array}$ & Scapes & 1467 & 6 & 390 & 26.7 & 998 & 15 & 304 & $30-5$ \\
\hline $\begin{array}{l}\text { Cyclamen } \\
\text { persicum }\end{array}$ & Pedicels & 1118 & 6 & 447 & $40-4$ & 807 & 3 & 194 & $24 \cdot 1$ \\
\hline
\end{tabular}

$s$, Standard deviations; $V_{e}$, coefficient of variation.

TA BLE 2. Energy contents and construction costs

\begin{tabular}{|c|c|c|c|c|c|c|c|}
\hline Species & $\begin{array}{l}\text { Age of } \\
\text { axes } \\
\text { (years) }\end{array}$ & $\begin{array}{c}\text { Calorific } \\
\text { energy } \\
\text { content } \\
\left(\mathrm{kJ} \mathrm{g}^{-1}\right)\end{array}$ & $\begin{array}{c}\text { Ash } \\
\text { content } \\
\text { (\% dry } \\
\text { mass) }\end{array}$ & $\begin{array}{c}\mathrm{N} \\
\text { content } \\
\text { (\% dry } \\
\text { mass) }\end{array}$ & $\begin{array}{l}\text { Energy } \\
\text { content of } \\
\text { ash-free } \\
\text { substance } \\
\left(\mathrm{kJ} \mathrm{g}^{-1}\right)\end{array}$ & $\begin{array}{c}\text { Energy } \\
\text { content of } \\
\text { non-storage } \\
\text { substances } \\
\left(\mathrm{kJ} \mathrm{g}^{-1}\right)\end{array}$ & $\begin{array}{c}\text { Construction } \\
\text { cost } \\
\left(\mathrm{kJ} \mathrm{g}^{-1}\right)\end{array}$ \\
\hline Ephedra foeminea & 2 & $18 \cdot 13$ & 7.5 & 1.35 & $19 \cdot 60$ & $16 \cdot 14$ & $22 \cdot 01$ \\
\hline Pachysandra terminalss & $\begin{array}{l}1 \\
2 \\
3\end{array}$ & $\begin{array}{l}17 \cdot 33 \\
16 \cdot 86 \\
16 \cdot 71\end{array}$ & $\begin{array}{l}6 \cdot 3 \\
6 \cdot 7 \\
6 \cdot 8\end{array}$ & $\begin{array}{l}1.32 \\
1.31 \\
0.94\end{array}$ & $\begin{array}{l}18.49 \\
18.06 \\
17.93\end{array}$ & $\begin{array}{l}13.05 \\
11.82 \\
12.28\end{array}$ & $\begin{array}{l}21 \cdot 08 \\
20-46 \\
20 \cdot 15\end{array}$ \\
\hline Taxus baccata & $\begin{array}{l}1 \\
2\end{array}$ & $\begin{array}{l}19 \cdot 35 \\
19.00\end{array}$ & $\begin{array}{l}5 \cdot 9 \\
5 \cdot 2\end{array}$ & $\begin{array}{l}1.29 \\
0.85\end{array}$ & $\begin{array}{l}20-49 \\
20-19\end{array}$ & $\begin{array}{l}16.30 \\
16.65\end{array}$ & $\begin{array}{l}23.41 \\
23 \cdot 10\end{array}$ \\
\hline Taraxacum officinale & Scapes & $15 \cdot 56$ & $9 \cdot 6$ & $1 \cdot 18$ & $17 \cdot 22$ & $9 \cdot 54$ & 18.92 \\
\hline Cyclamen persicum & Pedicels & 14.59 & $8 \cdot 3$ & 1.60 & 15.91 & 10.77 & 17.83 \\
\hline
\end{tabular}

stems it is known that the destruction in most cases starts with a compression failure, often as a shear (Archer, 1987; Wessolly, 1988). Dierks and Hafner (1987) obtained similar results for the herbaceous stalks of Cyclamen. Therefore, the ultimate compression load is of particular importance. We made some bending experiments with Ephedra and Pachysandra stems and surveyed the fracture area by SEM. Also, our findings point to a failure by compression, which in most cases was attributed to a separation of the inner and outer tissues of the stem, probably because the cortex is less compressible than the pith.

The lowest Bic-values are found for the lignified tissues (2 year old) of axes of Ephedra and Taxus. In the latter species, the Bic-values of twigs in the first year (weak lignification before secondary thickening starts) are comparable to those of herbaceous Pachysandra stems. With ongoing lignification of the twigs the Bic-values for compression decline by about one-half. In the stems of Pachysandra, which do not form wood, no such effect is observed. In woody stems, where the fraction of wood rises during secondary thick- ening, the Bic-values as a threshold will reach eventually the values measured for the living wood of the respective species.

High Bic-values for tension are found in the short-lived stalks of Taraxacum and Cyclamen; however, the Bic-values for compression are in the usual range for herbaceous stems.

\section{Energy values}

The energy values, which we then used for the calculation of the constructive expenditure values, are shown in Table 2. The calorific energy contents are in the usual range, as described by Pipp and Larcher $(1987 a, b)$; they are higher for lignified than for herbaceous tissues. The same is true for the energy content of the ash-free substance. In Taxus twigs, a high calorific energy value is found even in the first year, at least partly due to a high content of storage substances. The variation of the calorific energy contents throughout a year in Ephedra and Taxus (2 years old) as well as in Pachysandra ( 1 year old) is always less than $0.5 \mathrm{~kJ} \mathrm{~g}^{-1}$. These 
T A B LE 3. Constructive expenditure values $\mathrm{K}$ (calculated using construction costs and using energy contents of non-storage substances) and relation of $\mathrm{K}$ to the average lifespan

\begin{tabular}{|c|c|c|c|c|c|c|c|c|}
\hline Species & $\begin{array}{l}\text { Age of } \\
\text { axes } \\
\text { (years) }\end{array}$ & $\begin{array}{l}\text { Bic-values for } \\
\text { compression } x \\
\text { construction } \\
\text { cost } K_{p}\end{array}$ & $\begin{array}{c}\text { Bic-value for } \\
\text { compression } x \\
\text { energy content } \\
\text { of non-storage } \\
\text { substances }\end{array}$ & $\begin{array}{c}\text { Bic-value for } \\
\text { tension } x \\
\text { construction } \\
\text { cost } K_{t}\end{array}$ & $\begin{array}{l}\text { Bic-value for } \\
\text { tension } x \\
\text { energy content } \\
\text { of non-storage } \\
\text { substances }\end{array}$ & $\begin{array}{c}\text { Average } \\
\text { lifespan } \\
\text { (days) }\end{array}$ & $\frac{K_{p}}{\text { lifespan }}$ & 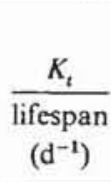 \\
\hline $\begin{array}{l}\text { Ephedra } \\
\text { foemunea }\end{array}$ & 2 & 1360 & 1000 & 370 & 270 & $>900$ & $<1.5$ & $<0.4$ \\
\hline $\begin{array}{c}\text { Pachysandra } \\
\text { terminalis }\end{array}$ & $\begin{array}{l}1 \\
2 \\
3\end{array}$ & $\begin{array}{l}2635 \\
3490 \\
3305\end{array}$ & $\begin{array}{l}1630 \\
2015 \\
2015\end{array}$ & $\begin{array}{r}1405 \\
950 \\
870\end{array}$ & $\begin{array}{l}870 \\
550 \\
530\end{array}$ & $\begin{array}{r}>1000 \\
700 \\
350\end{array}$ & $\begin{array}{c}<2.65 \\
5.0 \\
9.4\end{array}$ & $\begin{array}{r}<1.4 \\
1.4 \\
2.5\end{array}$ \\
\hline $\begin{array}{l}\text { Taxus } \\
\text { baccata }\end{array}$ & $\begin{array}{l}1 \\
2\end{array}$ & $\begin{array}{l}2970 \\
1425\end{array}$ & $\begin{array}{l}2070 \\
1030\end{array}$ & $\begin{array}{l}980 \\
865\end{array}$ & $\begin{array}{l}685 \\
625\end{array}$ & $\begin{array}{l}>2000 \\
>1600\end{array}$ & $\begin{array}{l}<1.5 \\
<0.9\end{array}$ & $\begin{array}{l}<0-5 \\
<0-55\end{array}$ \\
\hline $\begin{array}{c}\text { Taraxacum } \\
\text { officinale }\end{array}$ & Scapes & 2775 & 1400 & 1890 & 950 & $<40$ & $>69$ & $>47$ \\
\hline $\begin{array}{r}\text { Cyclamen } \\
\text { persicum }\end{array}$ & Pedicels & 1990 & 1205 & 1440 & 870 & $<80$ & $>25$ & $>18$ \\
\hline
\end{tabular}

variations are much smaller than the degree of accuracy which can be reached in measuring the Bic-values.

The construction cost is also much higher in lignified tissues and lower in herbaceous ones, especially in shortlived stems. Since the construction cost for perennial axes does not vary much throughout the year (Diamantoglou et al., 1989 b) it seems particularly appropriate to consider it as an energy-value for the calculation of the constructive expenditure values.

The energy content of the non-storage substances, which can be assumed to be mainly the energy value of the bearing tissues, is also relatively constant throughout a year (Diamantoglou et al., 1989 b), but to obtain the values one has to acquire more experimental data. Therefore, we prefer to use the construction cost as an energy value; however, for preliminary descriptions the calorific energy values may be used for the calculations.

For the lignified tissues of Ephedra we had found that the energy of the ash-free substance is rather well correlated to the crude fibre content (Diamantoglou et al., 1989a). The latter, on the other hand, is related to the energy content of the bearing tissues. Therefore, the energy content of the ashfree substance may also be a good measure to get approximate values of the construction expenditure.

\section{Constructive expenditure values}

Low values of the constructive expenditure mean a high efficiency/cost ratio. Generally, herbaceous axes show higher values than woody stems, especially regarding compression (Table 3). In Taxus, the constructive expenditure value declines with lignification. This may be expected, because the construction cost is relatively high, but after the construction no further expenditure is necessary for wood. The constructive expenditure for compression in lignified Taxus is similar to that of Ephedra, which shows the lowest of the measured values. The mechanical efficiency of the different tissues (measured as Bic-values) has a greater influence on the constructive expenditure values than the energy values have. This results mainly from the fact that the energy values are determined predominantly by the chemical composition of the plant material and therefore may only fluctuate in a limited range (Pipp and Larcher, $1987 a)$.

When the energy contents of non-storage substances, instead of the construction costs, are used for the calculation of the constructive expenditure values, such values also show the same trend with the exception of the scapes of Taraxacum, where a major difference is observed. This is mainly caused by the high sugar content of the scape-tissues ( $25 \%$ of dry weight). Therefore, the constructive expenditures calculated using the construction costs are higher for Taraxacum than for Cyclamen; however, when the energy content of non-storage substances is used instead, the expenditure values are rather similar. The high amount of sugars in Taraxacum is probably used in fruit development. This points to the fact that in flower and fruit stalks functions other than those requiring mechanical stability are essential. In Pachysandra, a similar but less marked effect is recognizable. This is not surprising because in all green stems photosynthesis is a more or less important additional function.

\section{Constructive expenditure values in relation to lifespan}

Table 3 also shows the constructive expenditure values (calculated using the construction costs) related to the average lifespan. Predation by animals and other processes leading to a premature death of a plant or a plant organ have to be ignored for these calculations. Low values are found for lignified tissues, which are effective long-term constructions. With an increasing amount of wood in the stems, the values are declining further, as can be seen from the data for compression in Taxus. In Pachysandra, where lignification is very weak, there is no decline but a rise occurs because the stems have a rather limited lifespan. 
Naturally, the short-lived stalks of the flowers show high values, which are somewhat lower in Cyclamen than in Taraxacum. The pedicels of Cyclamen during fruit-ripening gradually become prostrate, the fruits are laid down and the pedicels then have no further significant bearing-power. The values for Cyclamen would also be lower than those for Taraxacum, if the life spans used for calculation were considered to be identical. Probably the very high values for Taraxacum are caused by the storage function of the scapes, whereas the Cyclamen pedicels primarily have bearing and transport functions. Because of the transport functions, which are very important for flower and fruit stalks, these axes generally need a minimum area of vascular bundles. According to the Bic-values and the constructive expenditure, this area-at least in the species investigated-seems to be distinctly larger than is necessary for mechanical reasons.

\section{Conclusions}

From our results it may be seen that the Bic-method can successfully be used to obtain knowledge of the mechanical properties of anisotropic plant axes, where stress-strain curves do not lead to unequivocal results. Furthermore, the constructive expenditure values, which are calculated using energy contents, perhaps may be a useful quantitative value in ecological investigations. We are now analysing other species of different anatomical and ecological qualities as well as of different systematic positions. Furthermore, the influence of the water content of tissues and of turgor pressure on the mechanical properties in the herbaceous species can be investigated by the methods described. Some preliminary results were published earlier (Kull and Herbig, 1989) and some reflections on possible ecological applications of the method are discussed by Kull (1990). Furthermore, the Bic-values of plant axes may be included in general Bic/ $\lambda$-diagrams (for example Otto, 1985a) and in this way compared directly with other constructions in nature and engineering.

\section{ACKNOWLEDGEMENTS}

Thanks are due to Dr R. Blum for stress-strain measurements, to Dr Martin Schliephacke and Dipl.-Biol. Ulrike Vallon for experimental help, to Dr L. Wessolly for valuable discussions, and to Mrs B. Solis-Schreiter for correction of the English. This work was supported by the Deutsche Forschungsgemeinschaft (SFB 230: Natürliche Konstruktionen).

\section{LITERATURE CITED}

ARCHER, R. R., 1987. Growth Stresses and Strains in Trees, 240pp. Springer, Berlin.

Dinmantoglou, S. and KulL, U., 1982. Die Jahresperiodik der Fettspeicherung und ihre Beziehungen zum Kohlenhydrathaushah bei immergrünen mediterranen Holzpflanzen. Acta Oecologica (Oecologia Plantarum) 3, 231-248.

_ and - 1988. Der Stickstofthaushalt immergrūner mediterraner Hartlaubblâtter. Flora 180, 377-390.

— Rhizopoulou, S., Herbig, A. and Kull, U., 1989a. Seasonal trends in energy content and storage substances in the mediterranean shrub Ephedra. Acta Oecologica (Oecologia Plantarum) 10, 263-274.

,-- and KULL, U., $1989 \mathrm{~b}$. Energy content, storage substances, and construction and maintenance costs of Mediterranean deciduous leaves. Oecologia 81, 528-533.

Dierks, K. and HAFNER, L., 1987. Mechanical properties of the Cyclamen stalks and their structural basis. In Cytomechanics, eds J. Bereiter-Hahn, O. R. Anderson and W.-E. Reif, pp. 242-246. Springer, Berlin, Germany.

Distel barth, H., Kull, U. and Jeremias, K., 1984. Seasonal trends in energy contents of storage substances in evergreen gymnosperms growing under mild climate conditions in Central Europe. Flora $175,15-30$.

KULL, U., 1990. Vegetationsverhāltnisse in Trockengebieten und die Leichtbauweise von Pflanzen. Jahreshefte der Gesellschaft für Naturkunde in Württemberg 145, 5-33.

and Herbig, A., 1989. Konstruktion, Leichtbau and Ökonomie bei Pflanzen. Mitteilungen des SFB 3, 125-132.

Merino, J., FiEL. , C. and MOONEY, H. A., 1984. Construction and maintenance costs of mediterranean-climate evergreen and deciduous leaves. II. Biochemical pathway analysis. Acta Oecologica (Oecologia Plantarum) 5, 211-229.

Mosbrugger, V., 1990. The tree habit in land plants. Lecture Notes in Earth Sctences 28, 161 pp. Springer, Berlin, Germany.

Nachtigall, W., Wisser, C. M. and Wisser, A., 1986. Pflanzenbiomechanik (Schwerpunkt Gräser). Konzepte SFB 230 24, 172 pp. Stuttgart, Germany.

Oтто, F., 1954. Das hängende Dach 160 pp. Bauwelt-Verlag, Ullstein, Berlin (reprint 1990: DVA, Stuttgart).

- 1968. Biotechnik-7. Natur und Leichtbau, Vergleich der Konstruktion (without pagination). DIA Ausstellungstafeln, Berlin, Germany

—_, 1985a. Leicht. Konzepte SFB 230 8, 143 pp. Stuttgart, Germany. , 1985b. Tragende Lebewesen. Konzepte SFB 230 9, 128 pp. Stuttgart, Germany.

PIPP, E. and LARCHER, W., 1987 a. Energiegehalte pflanzlicher Substanz I Erfassung und Verarbeitung des Datenmaterials. Sitzungsberichte der Österreichischen Akademie der Wissenschaften, mathematischnaturwissenschaftliche Klasse, Abteilung I, 196, 37-66.

- and - 1987b. Energiegehalte pflanzlicher Substanz. II Ergebnisse der Datenverarbeitung. Sitzungsberichte der Österreichische Akademie der Wissenschaften, mathematisch-naturwissenschaftliche Klasse, Abteilung I 196, 249-310.

RASDORSKY, W., 1928. Über das baumechanische Modell der Pflanzen. Berichte der deutschen Botanischen Gesellschaft 46, 48-104.

- 1937. Über die Baumechanik der Pflanzen. IV. Die Skelett (Bewehrungs-) Gewebe des Pflanzenkörpers und die mechanischen Eigenschaften derselben. Biologia Generalis 12, 359-398.

Schaur, E., 1979. Grundlagen Form-Kraft-Masse Basics: FormForce-Mass, I (bilingual text). Mitteilungen des Instituts für Leichte Flächentragwerke der Unversität Stuttgart (IL) 21, 190 pp. K. Krämer, (Komm.-Verlag), Stuttgart, Germany.

SCHWENDENER, S. 1874. Das mechanische Prinzip im anatomischen Bau der Monokotylen. Mit Dergleichendem Ausblick auf die übrigen Pflanzenklassen. 179 pp. Engelmann, Leipzig, Germany.

Spatz, H.-Chr., Speck, T. and Vogellehner, D., 1990. Contributions to the biomechanics of plants. II Stability against local buckling in hollow plant stems. Botanica Acta 103, 123-130.

SPECK, T. and VOGELlfHNER, D., 1988. Biophysical examinations of the bending stability of various stele types and the upright axes of early 'vascular' land plants. Botanica Acta 101, 262-268.

- Spatz, H.-Chr. and VogellehNer, D., 1990. Contributions to the biomechanics of plants. I Stabilities of plant stems with strengthening elements of different cross-sections against weight and wind forces. Botanica Acta 103, 111-122.

UlLRICH, H., 1951. Über die Prinzipien pflanzlicher Festigkeitsverhăltnisse, insbesondere bei Holzpflanzen. Berichte der deutschen Botanischen Gesellschaft 64, 275-283.

VINCENT, J. F. V., 1982. Structural biomaterials, 206 pp. Macmillan, London, UK.

Wainwright, S. A., Biggs, W. D., Currey, J. D. and Gosline, J. M., 
1976. Mechanical Design in Organisms, 423 pp. Arnold, London, UK.

Wessolly, L., 1988. Die natürliche Konstruktion Baum also intelligentes statisch-dynamisches System. Mitteilungen des SFB 230 2, 203-212.

Willlams, K., Percival, F., Merino, J. and Mooney, H. A., 1987.
Estimation of tissue construction cost from heat of combustion and organic nitrogen content. Plant, Cell and Environment 10, 725-734.

Yoshie, F., ARa, H., Nakashima, H. and Kawano, S., 1990. Seasonal changes in nitrogen fractions of Pachysandra terminalis, a forest evergreen chamaephyte. Physiologia Plantarum 79, 7-14. 